\title{
PENINGKATAN HASIL BELAJAR DAN SELF EFICACY SISWA MELALUI MODEL PEMBELAJARAN CAROUSEL FEEDBACK DAN SHOWDOWN PADA MATA PELAJARAN KEWIRAUSAHAAN (Studi Kasus Pada SMA Negeri 1 Bengkayang)
}

\author{
Yosua Damas Sadewo ${ }^{1)}$ dan Pebria Dheni Purnasari ${ }^{2)}$ \\ ${ }^{1}$ Program Studi Kewirausahaan, Sekolah Tinggi Ilmu Manajemen Shanti Bhuana \\ ${ }^{2}$ Program Studi Manajemen, Sekolah Tinggi Ilmu Manajemen Shanti Bhuana \\ 1,2, Jalan Bukit Karmel, No.1 Sebopet, Kabupaten Bengkayang, Kalimantan Barat 79214 \\ E-mail : yosua.damas@shantibhuana.ac.id ${ }^{1)}$, pebria.dheni@shantibhuana.ac.id ${ }^{2)}$
}

\begin{abstract}
ABSTRAK
Tujuan penelitian ini adalah untuk meningkatkan hasil belajar pada mata pelajaran kewirausahaan dan self efficacy siswa kelas X di SMA N 1 Bengkayang setelah siswa mengikuti pembelajaran dengan menggunakan model Carousel Feedback and Showdoun. Penerapan model Carousel Feedback and Showdoun merupakan solusi dari permasalahan yang terjadi di kelas yakni hasil belajar serta self efficacy siswa yang rendah. Penelitian ini merupakan penelitian tindakan kelas (PTK) yang dilakukan secara kolaboratif. Adapun subjek penelitian ini adalah siswa kelas X di SMA N 1 Bengkayang. Teknik pengumpulan data yang digunakan adalah teknis tes, observasi, dan angket, sedangkan analisis data menggunakan analisis deskriptif kuantitatif. Data yang diperoleh berdasarkan tes selanjutnya dianalisis guna diketahui ketuntasan belajar siswa, selanjutnya self efficacy diukur melalui angket. Berdasarkan hasil penelitian dan analisis data yang dilakukan maka diketahui adanya peningkatan hasil belajar dan self efficacy. Ketuntasan hasil belajar pada siklus I adalah sebesar 55,56\%. Hal ini menunjukkan adanya peningkatan sebesar 22,23\% dari kondisi awal di mana ketuntasan hanya mencapai $33,33 \%$. Hasil analisis ketuntasan belajar siklus II diketahui bahwa ketuntasan siswa mencapai 83,33\% sehingga ketuntasan ini melampaui indikator ketuntasan yang ditentukan. Adapun peningkatan ketuntasan belajar dari siklus I ke siklus II adalah sebesar $27.77 \%$. Selain adanya peningkatan hasil belajar juga terjadi peningkatan self efficacy diri yakni dari $73,56 \%$ menjadi 85,34\%, sehingga dapat disimpulkan bahwa model Carousel Feedback and Showdoun mampu meningkatkan hasil belajar dan self efficacy siswa kelas X pada mata pelajaran kewirausaahaan di SMA N 1 Bengkayang.
\end{abstract}

Kata Kunci:Hasil Belajar, Self Eficacy, Model Carousel Feedback and Showdown, Pendidikan Kewirausahaan, PTK

\section{PENDAHULUAN}

Kewirausahaan merupakan salah satu faktor penentu kemajuan ekonomi suatu bangsa (Kurnianto dan Putra, 2012). Pertumbuhan dan kemajuan ekonomi ini akan memicu majunya suatu bangsa. Kegiatan wirausaha menjadi salah satu faktor bagi kemajuan bangsa, di mana kegiatan wirausaha akan meningkatkan laju ekonomi dan kemajuan ekonomi sendiri merupakan salah satu faktor dalam memajukan suatu bangsa dan negara.

Kewirausahaan adalah sesuatu yang sangat menguntungkan bagi negara Indonesia mengingat banyaknya angka pengangguran di negara Indonesia. Jumlah penggangguran di Indonesia hampir separuh dari jumlah lulusan perguruan tinggi (Kurnianto dan Putra, 2012). Jumlah wirausaha di Indonesia sendiri tergolong rendah di banding negara lainnya. Kondisi tersebut sangat mengkhawatirkan mengingat persaingan untuk mendapatkan pekerjaan akan semakin ketat dengan datangnya Revolusi Industri 4.0. Hal ini menunjukkan bahwa kegiatan berwirausaha masih sangat perlu disosialisaikan lebih untuk menekan angka pengangguran. Menjawab persoalan tersebut, maka Pendidikan Kewirausahaan telah menjadi pilihan alternatif yang disediakan di jenjang pendidikan, baik di Pendidikan Tinggi, Pendidikan Menengah maupun Pendidikan Dasar. Pendidikan kewirausahaan sendiri tengah menjadi kajian di berbagai kesempatan baik melalui diskusi, seminar, lokakarya maupun lesson learn dengan menghasilkan alumni yang sukses dalam berwirausaha (Wiranto, 2012). Kegiatan ini tentunya akan memberikan dorongan yang positif bagi para siswa untuk terus belajar dan nantinya dapat menggapai kesuksesan. Program pendidikan kewirausahaan selayaknya menyiapkan siswa untuk memiliki pengalaman untuk berwirausaha (Erickson \& Laing, 2016). Pendidikan kewirausaahaan diberikan sebagai bentuk upaya dalam menciptakan atau mencetak wirausaha yang mampu mengikuti perkembangan jaman (Sadewo \& Purnasari, 2018). Sudah sepatutnya bahwa peran pendidikan kewiraushaan di lingkungan pendidikan untuk dapat menciptakan lulusan yang mampu bersaing dan berkarya sehingga menghasilkan 
sesuatu yang inovatif dan bermanfaat (Sadewo, et al., 2019).

Tentunya untuk sampai pada tahap tersebut diperlukan sebuah komitmen dan semangat tinggi untuk menyalurkan pendidikan kewirausahaan melalui pembelajaran kewirausahaan yang baik. Pembelajaran yang baik adalah pembelajaran yang efektif dan menekankan pada pemberdayaan secara aktif. Sehingga ketika pembelajaran dapat efektif dan dapat membuat siswa aktif maka hasil yang didapatpun akan maksimal, hasil tersebut adalah hasil belajar mahasiswa (pemahaman).

Berdasarkan hasil observasi yang dilakukan peneliti kepada guru mata pelajaran kewirausahaan kelas X SMA Negeri 1. Ditemukan bahwa hasil belajar siswa pada mata pelajaran kewirausahaan kelas $\mathrm{X}$ pada semester I hanya mengalami ketuntasan sebesar $33,33 \%$ dari total 36 siswa, sehingga terdapat $66,67 \%$ siswa yang belum tuntas pada mata pelajaran kewirausahaan di semester I. Diduga hal tersebut terjadi karena mata pelajaran kewirausahaan merupakan mata pelajaran yang masih tergolong baru di SMA tersebut, sehingga mungkin siswa merasa asing dan kurang percaya diri dalam mengikuti pelajaran tersebut. Rasa kurang percaya diri ini sering dikenal sebagai self efficacy. (Sadewo \& Purnasari, 2019) menjelaskan bahwa self efficacy merupakan keyakinan maupun rasa percaya diri yang mampu mendorong individu dalam menggapai sesuatu. Rendahnya kepercayaan diri siswa berimbas kepada siswa yang merasa tidak percaya diri terhadap pemahaman mata pelajaran kewirusahaan dan ketidakpercayaan diri untuk menyampaikan gagasan ataupun menanggapi dalam pelajaran. Hal tersebut diduga memberikan dampak terhadap perolehan hasil belajar siswa kelas X SMA Negeri I pada mata pelajaran kewirausahaan semester I. Peneliti dan guru kelas kemudian bersepakat untuk menyelesaikan masalah tersebut dengan cara meningkatkan rasa percaya diri siswa melalui penerapan model pembelajaran kooperatif.

Pembelajaran kooperatif, bukan hanya hasil belajar siswa yang diharapkan meningkat melainkan juga peningkatan keterampilan sosial siswa yang ditandai kemampuan siswa untuk bekerja sama dengan siswa lainnya walaupun berbeda latar belakang sosial dan akademiknya. Terdapat berbagai macam model pembelajaran kooperatif dengan berbagai cara dan media yang relevan. Dalam penelitian ini akan digunakan pembelajaran kooperatif model carousel feedback and showdown. Carousel feedback dikembangkan oleh (Kagan \& Kagan, 2009). Lebih lanjut, (Kagan \& Kagan, 2009) mengartikan showdown merupakan model pembelajaran kooperatif yang terdiri dari 4-5 siswa yang heterogen. Masing-masing siswa dalam kelompok tersebut mempunyai tanggung jawab yang sama, yaitu menjadi ketua kelompok (kapten showdown) secara bergantian, mengerjakan soal yang diberikan guru, membandingkan, dan membahas soal-soal yang telah dikerjakan bersama anggota kelompoknya. Dalam pembelajaran kooperatif model showdown tidak hanya ditekankan pada aspek pengetahuan tetapi juga aspek kemampuan sosial siswa yang terdiri dari sikap saling membantu, sikap/pendapat yang menunjukkan ketidaksetujuan, memberi semangat kepada yang lain, kata-kata dalam berpendapat, memberi alasan, mengenalkan yang lain, melatih yang lain, memuji, menyelesaikan masalah, tanggung jawab, saling berbagi, melaksanakan peraturan, penerimaan kembali, toleransi, dan kerja sama.

Model tersebut akan diterapkan sebagai model pembelajaran di mata pelajaran kewirausahaan semester II. Sehingga dengan diterapkannya model tersebut maka diharapkan rasa kepercayaan diri siswa meningkat dan akan berpengaruh kepada peningkatan hasil belajar siswa. Pemilihan model Carousel Feedback ini dilakukan dengan memperhatikan teori dasar mengenai model Carousel Feedback yang telah dipaparkan sebelumnya serta berdasarkan hasil maupun temuan penelitian terdahulu yakni penelitian yang telah dilakukan oleh (Yusmanto, et al., 2017) di mana hasil penelitiannya menunjukkan bahwa model Carousel Feedback terbukti mampu meningkatkan kemampuan siswa. Selain itu penelitian dari (Martha, 2015) juga menunjukkan adanya peningkatan hasil belajar siswa setelah mengikuti pembelajaran dengan model Carousel Feedback and Showdown. Dengan demikian diharapkan melalui penerapan model Carousel Feedback and Showdown dapat meningkatkan kemampuan siswa. Sehingga tujuan dari penelitian ini adalah untuk mengetahui bahwa melalui penerapan model pembelajaran Carousel Feedback dan Showdown dapat meningkatkan hasil Belajar dan Self Eficacy siswa kelas X SMA Negeri 1 Bengkayang, terkhusus pada mata pelajaran Kewirausahaan.

\section{RUANG LINGKUP}

Dalam penelitian ini permasalahan mencakup upaya peningkatan hasil Belajar dan Self Eficacy Siswa Kelas X SMA Negeri 1 Bengkayang pada Mata pelajaran Kewirausahaan melalui penerapan Model Pembelajaran Carousel Feedback and Showdown. Penelitian hanya dilakukan di dalam mata pelajaran Kewirausahaan kelas X SMA Negeri I Bengkayang tentang upaya peningkatan hasil belajar dan self eficacy melalui penerapan Model Pembelajaran Carousel Feedback and Showdown. Rencana yang diharapkan adalah dengan penerpan model pembelajaran Carousel Feedback and Showdown, maka rasa percaya diri siswa meningkat sehingga berimbas kepada meningkatnya hasil belajar siswa kelas $\mathrm{X}$ di mata pelajaran kewirausahaan.

\section{BAHAN DAN METODE}

Penelitian ini memfokuskan pada peningkatan hasil belajar dan self efficacy pada pembelajaran kewirausahaan setelah siswa kelas $\mathrm{X}$ SMA $\quad \mathrm{N} \quad 1$ Bengkayang mengikuti pembelajaran dengan model Carousel Feedback and Showdown. XXX menyatakan 
hasil belajar adalah perubahan terhadap kemampuan seseorang yang dihasilkan dalam suatu proses belajar. Kemampuan ini berupa pengetahuan, sikap, dan keterampilan (Israwati, 2014). Pengertian hasil belajar juga dikemukakan oleh Bloom sebagaimana dikutip oleh (Suprijono, 2009) yang menyatakan bahwa hasil belajar merupakan capaian yang diperoleh yang mencakup kemampuan segi kognitif, afektif, dan psikomotorik. Paparan tersebut menunjukkan bahwa hasil belajar merupakan adanya peningkatan kemampuan siswa setelah mengikuti proses pembelajaran. Dalam penelitian ini hasil belajar yang dimaksud adalah hasil belajar berupa kemampuan kognitif yang diukur melalui tes dan afektif yang berupa self efficacy yang diukur melalui angket.

Self efficacy diartikan sebagai kepercayaan diri yang ada pada seseorang sehingga menolongnya dalam mencapai keberhasilan (Hidayat, 2011). Self efficacy memegang peran yang sangat penting dalam kehidupan sehari-hari merupakan faktor yang dapat mempengaruhi hasil belajar (Schunk, 2012). Hal ini sebagaimana diungkapkan oleh (Rustika, 2012) bahwa efikasi berperan penting dalam kehidupan sehari-hari, efikasi mendorong seseorang menggunakan potensi dirinya dengan optimal. Meninjau paparan tersebut, maka dalam dunia pendidikan, peran self efficacy sangat penting. Adanya self efficacy dalam diri siswa akan mendorong potensi siswa dalam belajar sehingga hal ini turut berdampak pada pencapaian hasil belajar.

Carousel Feedback and Showdown merupakan salah satu model pembelajaran cooperative learning yang digunakan guru dalam proses pembelajaran untuk melatih siswa menyelesaikan persoalan melalui proses penemuan data, hal ini dimaksudkan untuk mengembangkan ide dan memberikan evaluasi bagi kelompok lain (Effendi, et al., 2016). Carousel Feedback and Showdown juga diartikan sebagai suatu pembelajaran yang menekankan kegiatan kelompok dalam menyelesaikan soal-soal yang diberikan selanjutnya setiap kelompok berotasi ke kelompok lain untuk melakukan pengamatan serta mendiskusikan, memberikan tanggapan atas atas pekerjaan kelompok tersebut (Kagan \& Kagan, 2009). Kegiatan tersebut menunjukkan bahwa Carousel feedback bermanfaat agar siswa dapat mempraktikkan keterampilan evaluasi, mencermati dan mendiskusikan berbagai tugas, menunjukkan usaha dan mampu mengevaluasi pekerjaan orang lain serta mengungkapkan opini. Kemampuan tersebut tentu membutuhkan rasa percaya diri dalam hal ini dikenal sebagai self efficacy. Sehingga proses pembelajaran dengan menerapkan Carousel Feedback and Showdown dapat melatih siswa untuk memiliki self efficacy. Selain itu, rangkaian kegiatan dalam model Carousel Feedback and Showdown mendorong siswa untuk memiliki pemahaman terhadap materi, hal ini dikarenakan siswa harus mampu memberikan tanggapan dalam proses evaluasi yang dilakukan pada kelompok lain. Sehingga sejalan dengan seluruh proses dalam model Carousel Feedback and Showdown maka sangat memungkinkan untuk menumbuhkan self efficacy dan hasil belajar siswa.

Jenis penelitian yang digunakan adalah penelitian tindakan kelas (classroom action research) yang terdiri dari 2 siklus, setiap siklus terdiri dari 3 pertemuan yang meliputi kegiatan: planning (perencanaan), acting \& observating (tindakan dan pengamatan), reflecting (refleksi), dan revise plan (perbaikan rencana). Adapun tahapan pelaksanaan dalam PTK disajikan pada Gambar 1.

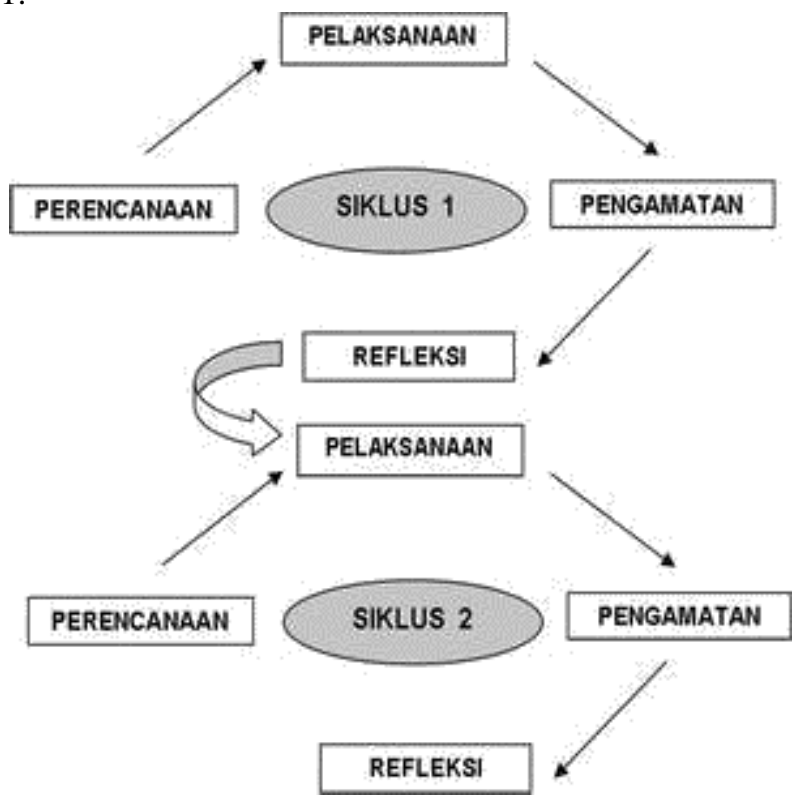

Gambar 1 Tahap Pelaksanaan PTK

Pada siklus I, model pembelajaran Carousel Feedback dilaksanakan pada pertemuan kesatu dan kedua sedangkan model pembelajaran Showdown dilaksanakan pada pertemuan ketiga. Pada siklus II, sama dengan pelaksanaan siklus I yaitu model pembelajaran Carousel Feedback dilaksanakan pada pertemuan pertama dan kedua sedangkan model pembelajaran Showdown dilaksanakan pada pertemuan ketiga.

Fokus Penelitian dalam penelitian Classroom action research ini adalah terjadi peningkatan hasil belajar dan self efficacy siswa pada mata pelajaran kewirausahaan melalui penerapan model pembelajaran Carousel Feedback dan Showdown pada siswa kelas X SMA Negeri 1 Bengkayang.

Sumber Data didapat dari seluruh kegiatan penelitian tindakan kelas (Classroom Action Research) yang dilakukan di Siswa kelas X SMA Negeri Bengkayang dengan penerapan model pembelajaran Carousel Feedback dan Showdown.

Dalam penelitian ini, teknik yang digunakan untuk pengumpulan data yaitu dengan: (1) Tes yang dilakukan oleh peneliti berupa pre-test dan post-test untuk melihat hasil belajar siswa terhadap pembelajaran kooperatif model Carousel Feedback dan Showdown; (2) Observasi dilakukan untuk mengamati proses pembelajaran yang 
meliputi aktivitas guru dan aktivitas siswa di kelas selama kegiatan pembelajaran kooperatif model Carousel Feedback dan Showdown dilaksanakan; (3) Angket yang diberikan kepada siswa sebagai subjek penelitian untuk mengetahui Self Efficacy mereka setelah diterapkannya pembelajaran kooperatif model Carousel Feedback dan Showdown; (4) Catatan lapangan yang dilakukan bersamaan dengan implementasi tindakan berisi tentang hal-hal yang terjadi selama berlangsungnya pembelajaran kooperatif model Carousel Feedback dan Showdown yang tidak terekam dalam lembar observasi; (5) Dokumentasi yang meliputi nilai siswa sebelum diberi tindakan, RPP, dan gambar atau foto selama berlangsungnya penelitian tindakan kelas.

\section{PEMBAHASAN}

Kondisi awal penelitian menunjukkan bahwa ketuntasan belajar siswa hanya mencapai 33,3\%. Ketuntasan ini menunjukkan rendahnya hasil belajar siswa pada saat kondisi awal yakni kondisi belum diterpakannya model Carousel Feedback and Showdown. Adapun presentase ketuntasan siswa pada kondisi pra siklus di sajikan pada Tabel 1.

Tabel 1 Ketuntasan Hasil Belajar Siswa Kelas X SMA N 1 Bengkayang Pra Siklus

\begin{tabular}{|c|c|c|}
\hline Kategori & Frekuensi & Persenntase \\
\hline Tuntas & 12 & 33,33 \\
\hline Tidak Tuntas & 24 & 66,67 \\
\hline Total & 36 & 100 \\
\hline Nilai Max & \multicolumn{2}{|c|}{80} \\
\hline Nilai Min & \multicolumn{2}{|c|}{65,65} \\
\hline Rata-Rata & \multicolumn{2}{|c|}{} \\
\hline
\end{tabular}

Tabel 1 menunjukkan bahwa ketuntasan belajar siswa berada jauh di bawah $50 \%$ yakni hanya mencapai $33,33 \%$. Ketuntasan belajar ini menunjukkan kriteria ketuntasan belajar yang rendah. Oleh karena itu diperlukan upaya untuk mengatasi hal tersebut yaki dengan menerapkan model Carousel Feedback and Showdown. Setelah dilakukan pelaksanaan pada siklus I maka diketahui hasil belajar siswa yang disajikan pada Tabel 2.

Tabel 2 Ketuntasan Hasil Belajar Siklus I

\begin{tabular}{|c|c|c|c|}
\hline No & Kategori & Frekuensi & Persenntase \\
\hline 1 & Tuntas & 20 & $55,56 \%$ \\
\hline 2 & Tidak Tuntas & 16 & $44,44 \%$ \\
\hline \multicolumn{2}{|c|}{ Total } & 36 & $100 \%$ \\
\hline & Nilai Max & \multicolumn{2}{|c|}{50} \\
\hline & Nilai Min & \multicolumn{2}{|c|}{55} \\
\hline & Rata-Rata & \multicolumn{2}{|c|}{} \\
\hline
\end{tabular}

Tabel 2 menyajikan ketuntasan belajar setelah dilakukan tes evaluasi akhir siklus dengan hasil bahwa jumlah siswa yang tidak tuntas lebih rendah jika dibanding dengan jumlah siswa yang tuntas. Nilai ratarata juga meningkat dari kondisi sebelumnya. Ini menunjukkan adanya peningkatan meskipun peningkatan tersebut belum mencapai indikator ketuntasan yang ditetapkan yakni sebesar $80 \%$ dari keseluruhan siswa mengalami ketuntasan belajar. Oleh sebab itu penelitian ini berlanjut pada pelaksanaan siklus berikutnya yakni siklus II.

Self Eficacy siswa selama mengikuti proses pembelajaran diukur melalui angket yang disebarkan ke masing-masing siswa. Setelah sebaran angket terisi maka dilakukan analisis yakni dengan menggunakan sistem (1) berikut.

$$
\text { Nilai }=\frac{\sum \text { Skor yang diperoleh }}{\Sigma \text { Skor maksimum }} \times 100 \%
$$

Dengan kriteria nilai sebagai berikut:

$\begin{array}{ll}80 \text { ke atas } & \text { : amat baik } \\ 70-79 & \text { : baik } \\ 56-69 & \text { : cukup } \\ 55 \text { ke bawah } & \text { : kurang }\end{array}$

Setelah dilakukan analisis terhadap self efficacy siswa setelah mengikuti pembelajaran Carousel Feedback and Showdown pada siklus I diketahui bahwa minat belajar siswa mencapai $73,56 \%$. Nilai tersebut berada pada kategori baik.

Selanjutnya dilakukan tindakan pada siklus II, proses pembelajaran siklus II merupakan perbaikan dari siklus I. Adapun hasilnya disajikan pada Tabel 3.

Tabel 3 Ketuntasan Hasil Belajar Siklus II

\begin{tabular}{|c|c|c|c|}
\hline No & Kategori & Frekuensi & Persenntase \\
\hline 1 & Tuntas & 30 & $83,33 \%$ \\
\hline 2 & Tidak Tuntas & 6 & $16,67 \%$ \\
\hline \multicolumn{2}{|c|}{ Total } & 36 & $100 \%$ \\
\hline & Nilai Max & \multicolumn{2}{|c|}{100} \\
\hline & Nilai Min & \multicolumn{2}{|c|}{75,05} \\
\hline \multicolumn{2}{|c}{ Rata-Rata } & \multicolumn{2}{c}{} \\
\hline
\end{tabular}

Berdasar Tabel 3 dapat diketahui bahwa ketuntasan belajar telah mencapai 83,33\%. Ketuntasan belajar pada siklus II telah melampaui indikator keberhasilan yang ditentukkan (80\%). Hasil ini menunjukkan bahwa telah tercapainya hasil penelitian yang diharapkan. Meskipun ada siswa yang dikategorikan belum tuntas namun jumlah siswa yang tidak tuntas tersebut jauh di bawah jumlah siswa yang tuntas. Adapun karakteristik siswa yang belum tuntas tersebut dikategorikan sebagai siswa yang mengalami kesulitan dalam belajar serta menduduki peringkat terbawah. Meskipun demikian karena ketuntasan telah melebihi indikator yang ditentukan maka penelitian ini dapat dikatakan berhasil.

Self Eficacy siswa pada siklus II juga diukur melalui angket. Setelah dilakukan analisis terhadap self efficacy siswa setelah mengikuti pembelajaran Carousel Feedback and Showdown pada siklus I diketahui bahwa minat belajar siswa mencapai $85,34 \%$. Nilai tersebut berada pada kategori amat baik

Hasil penelitian di atas menunjukkan adanya perbandingan perolehan hasil dari kondisi pra siklus, 
siklus I, dan siklus II. Ketuntasan belajar pada siklus I hanya mencapai $33,33 \%$ namun setelah dilakukan perbaikan yakni dengan menerapkan model Carousel Feedback and Showdown pada siklus I dan II. Adapun ketuntasan hasil belajar pada siklus I adalah sebesar $55,56 \%$. Hal ini menunjukkan adanya peningkatan sebesar $22,23 \%$. Jumlah ini menunjukkan peningkatan ketuntasan yang signifikan. Meskipun terjadi peningkatan, namun hasil belajar pada siklus I belum memenuhi indikator ketuntasan yang ditentukkan sehingga dilakukan perbaikan pada siklus II. Berdasar hasil analisis ketuntasan belajar siklus II diketahui bahwa ketuntasan siswa mencapai 83,33\% sehingga ketuntasan ini melampaui indikator ketuntasan yang ditentukan. Adapun peningkatan siklus I ke siklus II adalah sebesar $27.77 \%$. Hasil ini menunjukkan bahwa ketuntasan belajar mengalami peningkatan yang cukup tinggi. Adapun perbandingan ketuntasan dari kondisi awal, siklus I, dan siklus II disajikan pada Tabel 4.

Tabel 4 Perbandingan Ketuntasan Siswa

\begin{tabular}{|l|c|c|}
\hline \multicolumn{1}{|c|}{ Kondisi } & Tuntas & Tidak Tuntas \\
\hline Kondisi Awal & $33,33 \%$ & $66,67 \%$ \\
\hline Siklus I & $55,56 \%$ & $44,44 \%$ \\
\hline Siklus II & $83,33 \%$ & $16,67 \%$ \\
\hline
\end{tabular}

Selanjutnya gambaran mengenai perbandingan ketuntasan siswa disajikan pada Gambar 2.

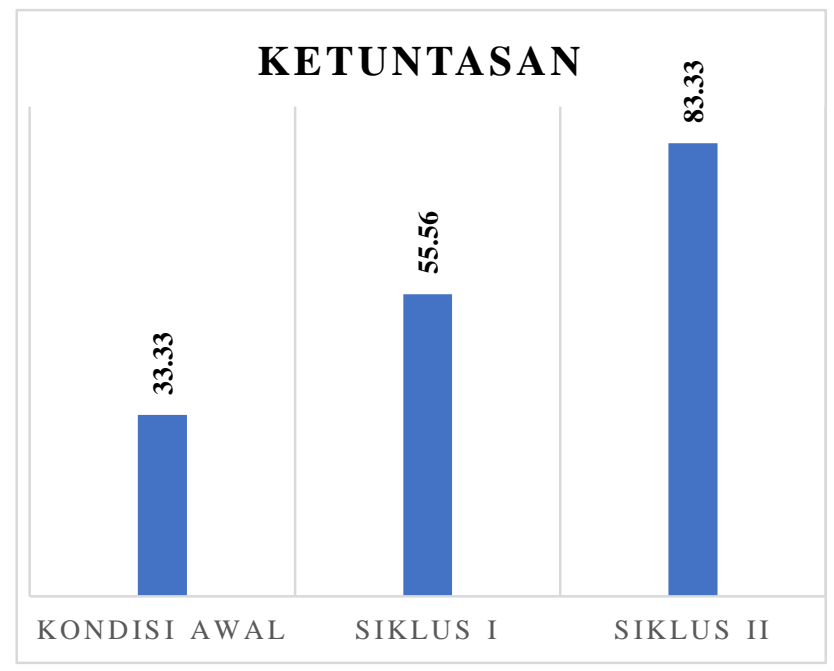

\section{Gambar 2 Ketuntasan Belajar Kondisi Awal, Siklus I, Siklus II}

Gambar 2 menunjukkan bahwa peningkatkan terjadi dari kondisi awal hingga pada siklus II. Peningkatan ini secara tidak langsung menunjukkan keberhasilan penerapan model Carousel Feedback and Showdowon. Selain adanya peningkatan hasil belajar juga terjadi peningkatan self efficacy diri yakni dari 73,56\% menjadi $85,34 \%$. Adapun perbandingan skor self efficacy disajikan pada Tabel 5 .
Tabel 5 Perbandingan Skor Self Efficacy

\begin{tabular}{|c|c|}
\hline Siklus & Nilai Self Efficacy \\
\hline I & $73.56 \%$ \\
\hline II & $85.34 \%$ \\
\hline
\end{tabular}

Tabel 5 menunjukkan perbandingan nilai self efficacy siswa dari siklus I hingga siklus II. Perbandingan ini diperoleh dari hasil analisis angket yang diberikan pada siswa setelah siswa mengikuti proses pembelajaran dengan model Carousel Feedback and Showdown. Berdasarkan Gambar 3, maka diketahui bahwa nilai self efficacy siswa pada siklus II lebih tinggi dibandinkan pada siklus I.

Hasil ini menunjukkan bahwa self efficacy diri siswa juga mengalami peningkatan setelah dilakukan pembelajaran dengan Carousel Feedback and Showdown. Hasil penelitian ini sejalan dengan hasil penelitian dari (Yusmanto, et al., 2017) dan (Martha, 2015) serta mendukung pendapat dari (Kagan \& Kagan, 2009) yakni model Carousel Feedback and Showdown mendorong siswa untuk aktif belajar sehingga meningkatkan pemahaman siswa dan berdampak pada meningkatnya hasil belajar.

\section{KESIMPULAN}

Berdasarkan pembahasan yang dilakukan maka diketahui adanya peningkatan hasil belajar dan self efficacy. Adapun ketuntasan hasil belajar pada siklus I adalah sebesar 55,56\%. Hal ini menunjukkan adanya peningkatan dari kondisi awal di mana ketuntasan hanya mencapai $33,33 \%$, pemberian tindakan yakni dengan penerapan model Carousel Feedback and Showdown memberikan dampak peningkatan dari kondisi awal ke siklus I sebesar 22,23\%. Hasil analisis ketuntasan belajar siklus II diketahui bahwa ketuntasan siswa mencapai $83,33 \%$ sehingga ketuntasan ini melampaui indikator ketuntasan yang ditentukan. Adapun peningkatan siklus I ke siklus II adalah sebesar 27.77\%. Hasil ini menunjukkan bahwa ketuntasan belajar mengalami peningkatan yang cukup tinggi. Selain adanya peningkatan hasil belajar juga terjadi peningkatan self efficacy diri yakni dari $73,56 \%$ menjadi $85,34 \%$. Hasil tersebut membuktikan bahwa penerapan model Carousel Feedback and Showdown pada pembelajaran kewirausahaan di kelas X SMA N 1 Bengkayang dapat meningkatkan hasil belajar dan self efficacy.

\section{SARAN}

Saran untuk penelitian dengan judul atau topik yang mengacu kepada penelitian ini kedepannya dapat lebih baik lagi, yakni dengan memperhatikan kebutuhan siswa serta memperhatikan langkah-langkah model Carousel Feedback and Showdown dalam penerapannya pada proses pembelajaran. Selanjutnya saran juga diberikan bagi para guru untuk dapat menerapkan model Carousel Feedback and Showdown secara khusu pada mata 
pelajaran kewirausahaan dan bahkan pada mata pelajaran lainnya.

\section{DAFTAR PUSTAKA}

Effendi, A., Soetjipto, B. E., \& Widiati, U. 2016. The Implementation of Cooperative Learning Model TSTS and Carousel Feedback to Enhance Motivation and Learning Outcome for Social Studies. IOSR Journal of Research \& Method in Education, 131-136.

Erickson, S. M., \& Laing, W. 2016. A Case Study In Connecting Academia with Bussiness. Journal of Entrepreneurship Education, 19(1), 1-8.

Hidayat, D. R. 2011. Teori dan Aplikasi: Psikologi Kepribadian dalam Konseling. Bogor: Ghalia Indonesia.

Israwati. 2014. Pengaruh Strategi Pembelajaran dan Motivasi Mengajar Guru Terhadap Hasil Belajar Siswa Kelas Awal SD Negeri 24 Banda Aceh. Jurnal Serambi Ilmu, 19(2), 87-90.

Kagan, S., \& Kagan, M. 2009. Cooperative Learning. California: Kagan Publishing.

Martha, J. A. 2015. Peningkatan Hasil Belajar, Aktivitas, Efikasi Diri Melalui Pembelajaran Model Carousel Feedback dan Showdown Pada Mata Pelajaran Kewirausahaan. Jurnal Konseling Indonesia, 1(1), 68-75.

Rustika, I. M. 2012. Efikasi Diri: Tinjauan Teori Albert Bandura. Buletin Psikologi, 20(1), 18-25.

Sadewo, Y. D., \& Purnasari, P. D. 2018. Hambatan dan Tantangan Program Studi Kewirausahaan di Wilayah Perbatasan. Mabis, 8(1).

Sadewo, Y. D., \& Purnasari, P. D. 2019. Peran Self Efficacy Terhadap Kemampuan Berwirausaha
Mahasiswa STIM Shanti Bhuana. Business, Economics and Entrepreneurship, 1(1), 32-38.

Sadewo, Y. D., Purnasari, P. D., \& Dimmera, B. G. 2019. Pendidikan Kewirausahaan Berbasis Ketahanan Nasional dan budaya Amare. Makasar: PT. Tohar Media.

Schunk, D. H. 2012. Learning Theories an Educational Perspective. Terjemahan oleh Eva Hamidah dan Rahmat Fajar. (E. H. Fajar, Trans.) Yogyakarta: Pustaka Pelajar.

Suprijono. 2009. Cooperative Learning. Yogyakarta: Pustaka Belajar.

Wiranto, S. 2012. Pelaksanaan Pendidikan Kewirausahaan di Pendidikan Tinggi. Jurnal Pendidikan dan Kebudayaan, 18(4), 454-466.

Yusmanto, H., Soetjioti, B. E., \& Djatmika, E. T. 2017. The Aplication of Carousel Feedback and Rond Table Cooperative Learning Models to Improve Student's Higher Order Thingking Skills (HOTS) and Social Studies Learning Outcomes. International Education Studies, 10(10), 39-49.

\section{UCAPAN TERIMA KASIH}

Ucapan terima kasih kami sampaikan kepada Institusi Sekolah tinggi Ilmu Manajemen Shanti Bhuana Bengkayang yang telah memberikan dana dalam pelaksanaan penelitian ini. Ucapan terima kasih juga diberikan kepada SMA Negeri I Bengkayang yang telah dengan sungguh-sungguh dalam bermitra dan membantu proses peneltian ini hingga selesai. Terima kasih juga disampaikan kepada Kepala Sekolah dan Guru Kewirausahaan SMA Negeri I Bengkayang yang telah memberikan ijin dan dukungannya dalam proses penelitian. Terima kasih kepada penulis kedua dan semua pihak yang telah membantu dalam pelaksanaan penelitian ini dari awal hingga selesai. 